\title{
JUDICIALIZING THE RIGHT TO THE CITY IN BRAZIL: STRATEGY FOR LEGAL MOBILIZATION AND FOR CITIZEN PARTICIPATION?
}

\section{JUDICIALIZANDO O DIREITO À CIDADE NO BRASIL: ESTRATÉGIA PARA A MOBILIZAÇÃO JURÍDICA E PARA A PARTICIPAÇÃO CIDADÃ?}

\section{Flavia Danielle Santiago Lima ${ }^{1}$}

\begin{abstract}
This paper explores the judicialization of the right to the city (urban environment) as a strategy of legal mobilization of groups and sectors, to guarantee time, opportunity and social pressure for their political pretensions in the public space and state organs. The study starts from a theoretical approach, with the deductive method, combined with a qualitative case analysis. Therefore, the research is supported by a bibliographical and documentary survey. It analyzes an episode that took place in Recife (Brazil), around the social and legal movement to prevent or mitigate the consequences of real estate development in an area of environmental interest Cais José Estelita. Based on the methodological approach of Judicial Politics, the legal protection of the right to the city in Brazil is described (Normative Theory) and evaluated the motivations of legal decisions, taking into account the judicialization as exercise of a political activity (Positive Theory). The general hypothesis is that democratic participation has in judicialization the possibility of obstructing public policies, broadening political costs for state decisions and the potential for negotiation in administrative channels.
\end{abstract}

Keywords: Judicialization. Legal mobilization. Right to the city. Urban environment. Democratic participation.

\section{Resumo}

Este artigo tem por objeto a judicialização do direito à cidade (meio ambiente urbano) como estratégia de mobilização legal de grupos e setores, garantindo tempo, oportunidade e pressão social para suas pretensões políticas no espaço público e órgãos estatais. O estudo parte de

\footnotetext{
${ }^{1}$ Professora do Programa de Pós-Graduação em Direito (Mestrado e Doutorado) da UFPE. Professora da Universidade Católica de Pernambuco (UNICAP) e da Universidade de Pernambuco (UPE). Doutora e Mestre em Direito Público (UFPE). Pesquisadora Visitante na Universitat de València. E-mail: flaviasantiago@uol.com.br
} 
uma abordagem teórica, com o método dedutivo, combinado com uma análise qualitativa de caso. Portanto, a pesquisa é apoiada por um levantamento bibliográfico e documental. Analisase o episódio ocorrido em Recife (Brasil), em torno do movimento social e jurídico para prevenir ou mitigar as consequências de empreendimento imobiliário em área de interesse ambiental Cais José Estelita. Com base na proposta da Política Judicial, é descrita a proteção normativa do direito à cidade no Brasil (Teoria Normativa) e questionados os fatores que motivam as decisões jurídicas, levando em consideração a judicialização como exercício de uma atividade política (Teoria Positivo) A hipótese geral é que a participação democrática tem na judicialização a possibilidade de obstruir as políticas públicas, ampliar os custos políticos para as decisões estatais e o potencial de negociação nos canais administrativos.

Palavras-chave: Judicialização. Mobilização legal. Direito para a cidade. Direito ao meio ambiente urbano. Participação democrática. 


\section{INTRODUCTION}

Is the judicialization of political conflict a good legal mobilization strategy for social groups? To answer that, we will explore the judicialization of the right to the city and to the urban environment from an episode that took place in the city of Recife, located in the Brazilian Northeast. In Recife, a social and judicial mobilization attempted to stop or, at least, mitigate the consequences of la real estate development in an environmentally important area in town the José Estelita Wharf - that occupies a total area of 101,700 square meters, and would require the demolition of historically significant warehouses.

We will discuss judicial mobilization as political litigation: the processes and strategies, by numerous groups, that turn political demands into judicial claims, even if they do not in fact result in winning lawsuits. Legal mobilization is defined by McCann $(2004$, p. 506) as a "dynamic dispute-oriented, interpretivist understanding of legal practice with insights from social movement theorizing about collective action based on 'political process." We will be examining legal mobilization according to Judicial Politics, a political science branch that analyzes political processes under which legal decisions are produced and enforced. Thus, we will combine methods both from the disciplines of Law and Political Science - in other words, taking into account normative and positive theories. The former prescribes the criteria that should be observed in any decision; the latter asks what factors motivate judicial decisions in the real world, as they are themselves political acts (SHAPIRO; SWEET, 2002, p. 24; WHITTINGTON, 2008; FRIEDMAN, 2005).

Considering constitutional doctrine as the normative element of the present work, we will present an outline of the discussion on the right to the city in the Brazilian judicial system in the context of Federal Constitution of 1988 (CRFB), that establishes a "ecological right" or a "social environmental right," allowing legal arguments for the assumption that there are limitations to the actions of economic agents in favor of collectivity.

After drafting this general framework, we will proceed to the case study, where we will describe judicial matters around the José Estelita Wharf and what time limitations, political and economic costs and administrative affairs meant for the litigating groups.

The study starts from a theoretical approach, with the deductive method, to confront the premises of the judicialization of public policies and legal mobilization with the concrete case. At this moment, the strategies of social movements - above all the "Ocupe Estelita" - will 
be described based on the contributions of the areas of communication and social sciences. The analysis of judicial processes and judgments will be qualitative, with emphasis on legal arguments regarding environmental legislation and in the decisions that had a direct impact on the dynamics of social mobilization. Therefore, the research is supported by a bibliographical and documentary survey.

Our general hypothesis is that the analysis of the judicialization of public policy not only should evaluate whether a claim is valid or not, but should also take into consideration factors such as time, opportunity, and social pressure as important strategic elements for political groups. As such, in calling forth the judicial system, democratic participation may obstruct public policy, increase the political cost for state decisions and potentially open negotiation avenues in public administration. So, the judicialization of conflicts can be an interesting strategy for excluded groups, as one of the mechanisms to reinforce citizen participation in the construction of the right to the city and to the urban environment.

\section{JUDICIALIZATION OF POLITICS: ONE OF THE INSTRUMENTS OF LEGAL MOBILIZATION}

Judicialization is a process under which rules, procedures, and judicial discourse come to pervade many aspects of life. Judicialization of politics, thus, pertains specifically to the new dynamic between courts and the political environment. It examines their interactions in institutional aspects and analyzes their impact on the behavior of political and judicial actors. These were first analyzed in the original book organized by Tate and Vallinder (1995).

The concept describes the institutional traits that incentivize assigning political claims to the courts, such as the existence of political democracy, the separation of powers with checks and balances, and a guarantee of fundamental rights. These rights are the very basis upon which groups that find themselves on the losing end of majoritarian decisions can appeal to the judicial system.

From a behavioral standpoint, the judicialization of politics is dependent upon the inclination of political actors (both the opposition and other interest groups) to utilize judicial procedures to get a recognition of certain rights that challenge the majority's wishes or even obstruct public policy, should they be able to do so (TATE; VALLINDER, 1995, p. 28-36).

There is a consensus on the necessary connection between judicial discourse and political aspirations (e.g. GALANTER, 1993, p. 124-126; SWEET, 2000, p. 206). In affirming rights 
through their decisions, courts are converted into a jurisdiction that responds to claims that are unheard by traditional representative channels. At the same time, the institutional configuration of the courts is attractive to minority groups: having the duty to examine certain claims with a degree of independence grants them the ability to go forward in themes of difficult-to-reach consensus between political actors and social sectors (NEJAIME, 2012, p. 665).

Therefore, political actors become strategically involved in the "game of law," where they see broader opportunities for debating moral issues and symbolic battles (grounded on material claims) between conflicting parties. In this sense, judicial initiatives are informed by these objectives and supported by "specialized, entrepreneuring lawyers" who find welcoming judges to adjudicate their claims (GALANTER, 1993, p. 124-126).

In the United States, the expansion of the judicial language has been called a "rights revolution," as it describes individual rights gains as well as an awareness about such rights, and, lastly, their protection by independent, leading activist judges.

In such a scenario, we should highlight the deliberate effort by activists - within organizations, attorney offices, or funding institutions (usually the government). This legal orchestra depends on continually litigating in support of civil rights and liberties, despite the great lawsuit costs. As such, specialized attorney offices, met by a supporting environment within academia, have contributed to this process (EPP, 1998, p. 18-20).

There have been prolific debates on legal mobilization, especially in Anglo-Saxon countries. According to Frances Kahen Zemans (1993), legal mobilization is defined by "a desire or want that is translated into a demand as an assertion of one's rights." Rights claims are converted into several mobilization instruments: political lobby, social movements, the media, and others. Among these, the adjudicating claims is one of the instruments available to those who are unable to find representation in the usual political institutions ${ }^{2}$.

Regardless of local circumstances (e.g. GINSBURG, 2003; SWEET, 2000; GLOPPEN; GARGARELLA; SKAAR, 2004), there has been a global movement towards directing to the judicial system conflicts and tensions inherent to the political process, and the same holds true for Brazil. The Federal Constitution, as one of the instruments of the democratic restoration in the country, attempted to redefine the "ways of reaching decisions in national politics." Among other measures, it empowered courts and other judicial instances, such as the Public

\footnotetext{
2 In the UK and Canada, despite the longstanding accusation of supporting privilege, the judicial system is now seen as an ally that strengthens the rights of minorities such as homosexuals, indigenous people, and other groups (DICKSON, 2007, p. 13).
} 
Prosecutor's Office, the Public Defender's Office, and the Attorney-General (CARVALHO, 2010, p. 186).

In practical terms, it adopted an analytic model for the "democratic transition," allowing the "translation of political demands into judicial language, making them legally actionable" (LIMA, 2014, p. 221). There was a clear Iberian (especially Portuguese) influence guiding this democratic and communitarian constitutional view ${ }^{3}$. The very concept of communitarian constitutionalism is interpreted according to "popular citizenship" ideas, which subject constituted officials to a collective understanding about the scope of their powers. Furthermore, social groups are eager to attain political representation by widening the circle of "allowed interpreters of the constitution" (CITTADINO, 2000).

Over the last decade, judicial institutions have become a relevant study subject for judicial scholars and political scientists, who have reached some degree of consensus on the judicialization of politics and social relations (VIANNA, 1999, 2007; CARVALHO, 2005, 2008; FALCÃO et al, 2011). It is a process that has been felt in the entire Brazilian judicial system, from smaller lawsuits concerning specific individual rights, to public class action suits, to challenging the tenets of public policy in the Federal Supreme Court, Supremo Tribunal Federal (VIANNA; BURGOS, 2002, CASAGRANDE, 2008; TAYLOR, 2007). However, what interests move the litigating parties into judicializing their claims?

Despite being different, activism and judicialization of politics are related insofar as the likelihood of success of the claim (evaluated against judicial criteria as well as the receptiveness of the court, verified by previous verdicts) is an incentive for judicial intervention.

Although there is still debate on whether judicial victories are effective for political change in the long run (ROSENBERG, 2008; TUSHNET, 2008) or cause backlash (POST; SIEGEL, 2007), a favorable decision certainly has positive effects for a cause. It raises its legitimacy, "[mobilizing] constituents, and [providing] much-needed publicity," besides being able to "generate elite support, pressure adversaries, and increase a social movement's bargaining power" (NEJAIME, 2011, p. 944).

Often the lawsuit process itself may be able to further the interests of the claimant, increasing political costs for majoritarian branches or causing economic losses for the opposing party by obstructing public policy and provoking "new negotiation rounds" with other political

\footnotetext{
${ }^{3}$ As pointed by Siqueira Castro (2005, p. 43), "it is legitimate to speak of an objective dimension of fundamental rights as values, since their judicial reach and scope (that is, the legitimate situations or forms of exercise) are determined, in part, by the recognition of the community, and not simply by the opinion (desire) or the claimant."
} 
actors. In such cases, time is of great relevance as a strategic factor for judicial mobilization, especially when coupled with other forms of activism. Thus, we may reason that even a legal defeat might not be entirely unfavorable to the claimant.

Losing, for social movements dedicated to a cause, may force a reorganization of internal priorities and external articulation, which would depend on the engagement and strategic vision of the activists involved. As noted by Douglas NeJaime (2011), internally, it is possible to reconstruct and re-contextualize the group's identity, increasing their mobilization potential, renewing their confidence in the cause and the awareness that there is a need to increase funding. When it comes to the relationship with government and the public, losses may also present an opportunity for redirecting focus and reviewing priorities. A movement can assess which instance of the administration (local, state, federal) and which branch (executive, legislative, judicial) will be more welcoming to their demands or interests and then ponder whether the judicial strategy is the most effective ${ }^{4}$. The degree of interaction and publicity may also come under review in order to obtain institutional wins - spreading public awareness about the importance of a counter-majoritarian judicial system, for example - and a better grasp of the importance of the right being claimed. In any case, any judicial battle depends on the rules and regulations that allow for arguing about the effectiveness of established rights. In the case we now turn to, on the protection of the urban environment (both cultural and artificial), which includes the right to the city, we can say that the rules give the debate in question broad support.

\section{BRAZILIAN ENVIRONMENTAL STATE: CONSTITUTIONAL GUARANTEE OF THE RIGHT TO THE CITY AND DEMOCRATIC PARTICIPATION}

The Federal Constitution of 1988 adopted a social and environmental state in which the government regulates economic activity, directs it, and conforms it to constitutional values and principles in order to achieve sustainable human and social development ${ }^{5}$. Much like most

\footnotetext{
4 "Overall, my functional account of litigation loss demonstrates that judicial setbacks may, counterintuitively, contribute to the process of reform by producing conversations that rely on the multiple (and conflicting) ways in which we think about courts' constraints and the role of those constraints in the process of social change." (NEJAIME, 2011, p. 941)

${ }^{5}$ Over the 20th century, the Brazilian constitutions have introduced provisions for environmental protection, repeatedly invoking a social function of property, but only insofar as it pertained resources such as water, forests, mineral ore, hunting and fishing, and other indirectly related themes. On the other
} 
constitutions of the 1980s, the failures of the social state were already well known regarding environmental issues, as it was too optimistic in regarding economic growth as a miraculous machine for progress and welfare (SILVA, 2002, p. 18).

Regardless, a defense of the environment, similarly to the social focus of the constitution, should follow from the state duty to respect and protect human dignity, being a "live update of the principle," in light of newer human values that are incorporated to its norms. Thus, minimal environmental guarantees must be enforced (SARLET; FENSTERSEIFER, 2010, p. 15). Further, it follows from the very basis of the social state, since the constitution enshrines a government that goes beyond the "minimum state" that merely limits the behavior of private parties, being supported by notions of legality, democracy, sociability, and sustainability (CANOTILHO, 1998, p. 23).

In that sense, CRFB innovates: it incorporates sweeping protections. In both of the provisions on the right to property, it establishes the "social function of property" (article 5, XXII and XXIII, articles. 170, II and III) and puts several restrictions to its enjoyment in place. For this reason, the constitution outlined criteria for verifying whether property serves its social function by distinguishing between urban (art. 182, restricted to the limitations of municipal regulations) and rural property (art. 186, which concerns adequate and rational use, the owners' and workers' welfare, labor regulations and the environment) (BRASIL, 1988).

We should point to the unprecedented move to dedicate a whole chapter to the subject, securing to all the "right to a balanced environment (...) being the state's and the collective's duty to defend it and preserve it for present and future generations" (article 255, caput, CRFB) (BRASIL, 1988). More than discussing its public or private dimension, the right to the city promotes the intersection between social function of property, democratic management of cities and sustainability of urban spaces (GUIMARÃES, 2017, p. 627).

Environmental guarantees are wide in scope (legally broad and indeterminate), related to the "interaction between natural, artificial, and cultural elements that enable the balanced development of life in all its forms" (SILVA, 1994, p. 2). As such, under the constitution and ordinary legislation, it encompasses:

hand, the protection of historic, cultural, or otherwise scenic landscapes was present in all constitutions of the previous century (MILARÉ, 2007, p. 146-147). 
1. the natural or physical environment (article 225, caput, and article 3, I, Law no. 6.938/81), dealing with the equilibrium between living beings and their surroundings, comprised of the earth, the water, the air, flora and fauna (BRASIL, 1988; BRASIL, 1981)

2. the artificial environment (article 225, with special protections outline in articles 5, XXIII, 21, XX, and 182, CRFB), "comprising the developed urban space, constituted by buildings (closed urban spaces) and public equipment (open urban spaces)" (FIORILLO, 2001, p. 20). (BRASIL, 1988)

3. the cultural environment (articles 215 and 216), consistent in the set of goods created by man and translate the history of a people, its formation and culture, and therefore have special value, forming our historic, artistic, touristic, archeological, and scenic heritage. (BRASIL, 1988)

4. the work environment (article 200, VIII, article 7, XXXIII, and article 196, CRFB), where people labor, for money or not, and must be in proper health, safety and dignity conditions. (BRASIL, 1988)

Therefore, a defense of the environment was raised to a principle of economic and financial order (article 170, VI) side by side with private property and free enterprise (article $170, \mathrm{II}$ and III), thus conditioning the latter rights.

From this broad protection, we get specific limitations to the right to property supported by general constitutional principles and specific, formal rules. Because of the regulatory movement of the 1980s, the institutional and material conformation of the state to the new constitutional guidelines resulted in greater environmental and urban protections.

In any case, we should point to the specificities of Brazilian federalism, which becomes a hindrance to the enforcement and protection of the environment (KRELL, 2005), especially when it comes to the coordination between state entities.

The Brazilian constitution establishes an atypical federation, composed of the Union, States, and Municipalities. It differentiates between legislative and administrative functions the latter tasked to the executive branch with the duty to enforce specific measures.

Article 24 establishes that both the Union and the States (including the Federal District) put norms in place to deal with environmental matters. The federal legislature is responsible for national laws, while the states should pass regional bills, and municipalities are charged with local ones. At the same time, only the Union, generally, may legislate over the right to property (article 22, I, II, III), although restrictions and conditions may apply at the three levels of government (BRASIL, 1988). 
In the urban environment, the general guidelines for municipalities were established by federal law - the so-called Statute of the Cities. The right to the city is considered, from its normative definition ${ }^{6}$, a complex subjective right, since it contemplates a diversity of rights (and legal positions) of different natures. Then the following elements are identified:

(i) the right to adequate housing; (ii) the right to adequate public services; (iii) the right to democratic management of the city; (iv) the right to urban mobility; ( $v$ ) the right to urban planning; (vi) the right to protection of the historical, artistic, cultural and landscape patrimony of the city; (vii) the right to protection of the environment in urban space; (vii) the right to basic sanitation; (xiii) the right to leisure (MELLO, 2017, p. 448).

Among those rules, we should emphasize the full development of the "social function of the cities," that must "control and organize the use of land, avoiding (...) real estate speculation that results in their underuse or non-use" (article 2, VI, "e", Law 10.257/01) (BRASIL, 2001). Other measures are delineated within the same law, concerning indeterminate ownership and positive and negative obligations (such as compulsory development, preemption rights, environmental and neighborhood impact studies, among others).

Thus, article 30 of the CRFB assigns to the municipalities the duty to legislate matters of local interest - something that includes urban environment issues. Municipalities are supposed to perform duties of environmental legislation and enforcement via new laws and administrative acts dealing with factual matters. These acts may be preventive (licenses, authorizations, permits, concessions, emission standards, environmental quality, limitations to the use of certain raw materials, imposition of technological level, environmental impact evaluations, and inspections) or repressive (administrative and criminal sanctions resulting from inspections) (MACHADO, 2007, p. 303).

Beyond traditional instruments of government, the very "ecological ideology" invoked by the constitution radiates its postulates to every level of the state in its relationship with society, shaping behavior towards environmental protection (BENJAMIN, 2007).

The Constitution, following democratic principles of participation and information, includes a series of devices that enable access to information (article 5, XXXIII), the right to petition (article 5, XXXIV, "a"), and individual and collective guarantees of class action and public civil action. It points to new ways of taking part in politics and engaging with the judicial system,

\footnotetext{
6 "Article 2. The purpose of urban policy is to order the full development of the social functions of the city and of urban property, by means of the following general guidelines:

I - guarantee of the right to sustainable cities, understood as the right to urban land, housing, environmental sanitation, urban infrastructure, transportation and public services, work and leisure for present and future generations. (BRASIL, 2001)
} 
with its converging premises of individualism, publicness and association that are needed to protect the aforementioned rights (BRASIL, 1988).

In this case, we mention a "individual premise" present in the constitution insofar as the use of private rights, acts, and resources, such as the defense of property, of the self, and various neighborhood actions are particularly valuable to protect the right to the environment, or the "diffuse interests to the environment." The publicness premise means that the environment is a public good of common use, and that the protection of the environment is an essentially public function. Lastly, the association premise is founded on the idea of a liberal democracy, "averse to the technocratic management of the environment, or to a government of environmental know-it-alls" (CANOTILHO, 2003, p. 493-508).

In short, the constitution - as well as several laws passed since - envisions a right to effective participation in the development and enforcement of environmental public policy. Under such a scenario, the government must act in tandem with all of those committed to the collective interests of society (NGOs, citizens, and institutional mechanisms) (MACHADO, 2007, p. 82).

It is recognized that, alongside the legal framework, the realization of the right to the city demands articulation and social mobilization, "whose challenge is to change in a concrete way the correlation of forces prevailing in Brazilian society - long dependent and subordinated to the interests of the patrimonialist sectors" (TRINDADE, 2012, p. 159). Therefore, to relate the different versions of the right to the city (social, political and juridical), it is necessary "the strengthening and emergence of strong urban social movements" (GUIMARÃES, 2017, p. 632).

This social pressure has, among others, a certain destination: all levels of the state should be restructured in order to achieve proper participation by the people. Legislative houses must debate laws on the matter. The executive branches should update their communication and participation practices to reflect newer developments. Finally, the judicial branch and the Public Prosecutor's office should embody these ideas in their rulings and other actions. 


\section{SOCIAL AND JUDICIAL MOBILIZATION IN BRAZIL: THE JUDICIALIZATION OF JOSÉ ESTELITA WHARF'S CASE IN RECIFE}

Recife is the ninth largest city in Brazil, having 1,633,697 inhabitants in 2017. Recife's metropolitan region is the fourth largest urban area in the country, with over 4 million people in 2017. In 2010, the city's density was 7,039.64 inhabitants per square kilometer (BRASIL, 2017).

The following discussion deals with the 101,700 square meter area along the Cabanga and Santa Rita docks, a place that still houses old train tracks and warehouses built in the 19th and 20th century to store and transport sugar, an important agricultural culture for the region's economy since the colonial period. The area has great scenic importance, for it is located in the many islands that comprised what has come to be called Old Recife.

The land had been owned by the Federal Railway Network (RFFSA), but it reverted to the Union when the company was dissolved. In 2008, it was bought in an auction by a consortium composed of local development companies, who wished to tear down the old warehouses and, in their place, build the New Recife project: a thirteen building complex (some of them over forty stories high) of commercial and residential use that would bring about significant urban and environmental impact to the region. Despite being a private enterprise, it was presented as a partnership with local and state governments (BARBOSA, 2017, p. 3) that attempted to cast it as a project for the "urban, social, and economic development of the city and the preservation of its history." Preventive measures stipulated by environmental legislation were not followed by the project, however. There was no environmental impact study, neighborhood impact study, permits from historic heritage organizations, licenses issued by public transportation and traffic control departments, nor approval by popular councils (FLORES; GOMES, 2017, p. 232).

For these reasons, many came to suspect that the New Recife project would simply replicate the usual model of occupation of the city rather than rethink its urban project to make it more inclusive and sustainable. To quickly sum up the objections from an urbanenvironmental standpoint, the project would clash with the surroundings' architecture, would have "catastrophic" effects on urban mobility, "would affect the current environmental configuration of the area, creating heat islands and excessive verticalization" and would promote "irreversible gentrification" on the region (COSTA, 2016, p. 79). 
Right to the city actions then led to the creation of various groups, of which Direitos Urbanos $^{7}$ (literally, "Urban Rights") - whose goal is to establish a debate on the current model of occupation and transformation of our cities - and \#OcupeEstelita - that is directly confronting with the New Recife project - are the most notable ones.

The activities of the latter had great effect on the project. The group was able to find strong support online (on their Facebook group as well as Twitter, Instagram, and Youtube accounts), produced videos, organized events (TORRES; CHRISTOFOLETTI, 2015; ALCÂNTARA; BORGES, 2015), and was a "massive presence in public hearings, debates, occupations, legal battles to challenge the New Recife" (our emphasis) (BARBOSA, 2017, p. 4-5). Actually, there was a clear strategy:

Using the internet consciously, and denouncing the government's inability to establish a dialogue between the representatives and the represented, celebrates a new way of thinking about politics, of seeing politics and doing politics. It celebrates, even, the possibility of communicating for citizenship (ALCÂNTARA; BORGES, 2015, p. 105).

The creation of these dialogue spaces took place in parallel to the engagement with legal instruments of participation, such as hearings in legislative houses and the Public Prosecutor's Office, posting proposals and taking part in the legislative process, and broadly exercising their right to petition the government.

Nevertheless, when traditional representation channels are not an effective means for reaching their goals, the groups that are excluded from decision processes also have at their disposal a very important tool: the judicialization of political conflict.

It's worth noting that the \#OcupeEstelita movement had an important institutional ally: the Public Prosecutor's Office - that has among its constitutional duties the "protection of social and public heritage, the environment, and other diffuse, collective interests" via public civil action (article 129, III, CRFB). (BRASIL, 1988)

In February 2013, the public civil action was filed ${ }^{8}$, that requested the cancellation of the judicial auction that allowed the consortium to purchase the land, for it did not observe rules of environmental and urban legislation: the cultural heritage preservation of the railway patio, presenting the required studies for appreciation by official institutions, the concession required permits, and others.

\footnotetext{
${ }^{7}$ https://www.facebook.com/DireitosUrbanos?fref=ts; http://direitosurbanos.wordpress.com/

8 Public Civil Action 0001291-34.2013.4.05.8300 (Federal Justice, Pernambuco), proposed by the Federal Prosecutor's Office against the New Recife Consortium, the Historic and Artistic Heritage Institute (IPHAN), and the Municipality of Recife. (BRASIL, 2016)
} 
In April 2014, the 12th Federal District Court decided "to suspend the decision issued by the Urban Development Council regarding the approval of projects pertinent to the Novo Recife project and, a fortiori, to prohibit Novo Recife Empreendimentos Ltda.", to start any demolition activities in the area (BRASIL, 2016).

During the same month, the decision was dialed back, authorizing the demolition of the warehouses of non-operational area of the railway patio at the José Estelita Wharf, because of an appeal by the New Recife Consortium. The regional court - Tribunal Regional Federal da 5 a Região - stated that "the nullity need not have been recognized and that, when it was decreed, the decision caused serious damage to the public order ", emphasizing, furthermore, that" there is an unshakable certainty: work will only be taken care of when all approvals are available ". (apud BRASIL, 2016)

The consortium gave a different scope to court decisions and, during the night, began to demolish the warehouses.

In May 2014, the area was effectively occupied by \#OcupeEstelita, preventing the destruction of the warehouses and any work on the project. The occupation lasted for 50 days and was accompanied by a large online campaign that guaranteed mobilization, support, and visibility to cultural actions taking place in the area (one of the presentations had an over 10,000 crowd) and the "negotiations with the Municipality, the Public Prosecutor's Office, and the New Recife Consortium" (FLORES; GOMES, 2017, p. 232-234).

During the same period, there was a judicial suspension of the administrative decision taken by the Urban Development Council (CDU) and, consequently, the demolition begun. The Consortium would only be able to resume development after going through the necessary approvals by official organizations and presenting adequate licensing to the city of Recife (BRASIL, 2016).

The judicial decision - from 12th Federal District Court - thus described the legal question and its interpretation by the different parties:

In the meantime, the decisions handed down by the Federal Regional Court of the 5th Region were unison to condition any construction / demolition on the premises to the issuance of the competent license, with the hearing of the federal agencies involved. Both the suspension of the injunction, and injunctions in court, emphasize this issue.

In summary, according to the decision (...) Novo Recife Empreendimento Ltda. is fully aware that the beginning of the intervention on area, without the prior granting of the competent license, is contrary to the grounds of the decisions that currently favor it, and therefore subject it again to the general power of caution of this Court. 
Given this premise, it should be noted that the local press reported that, at dawn on Thursday (22 May), the demolition of the properties began, including photos of the site (see the extracts obtained in this respect on the websites of news) and a "charter of services without building reform," apparently issued in favor of the defendant.

So, considering the signs of irregular innovation in the de facto situation, I determine ad cautelam the immediate suspension of any demolition / construction on site (BRASIL, 2016)

Shortly after, the Justice Court of Pernambuco (Tribunal de Justiça de Pernambuco) granted property reintegration to the New Recife Consortium, "as it is private urban property whose limitations were already put in place by the government through permits and licenses, and there was no justification for the protesters stay" ${ }^{\prime \prime}$ (BRASIL, 2018).

Police violence was employed to comply with the eviction decision in June 2014, something that caused a stir in various groups of society. The regional chapters of several professional associations, local universities, Direitos Urbanos, the Public Prosecutor's Office and Amnesty International all released official statements repudiating police brutality.

Reports show a change of strategy in the movement during this time, going from "physical occupation of a smaller area to judicial, political, and cultural acts over a greater area in the urban center" (COSTA, 2016, p. 81).

All following judicial decisions allowed the project to resume development, provided it was able to comply with regulations already in place.

In the administration, several public hearings took place in Recife (from July 2014 to April 2015) that culminated in the bill to change Recife's urban plan (2008) and the Law of Use and Occupation of Land, from 1996.

In May 2015, the City Council of Recife approved the Law no. 08/2015, concerning plans for the José Estelita, Santa Rita, and Cabanga Wharves. Voting this bill was an intensely heated affair, since the vote did not observe usual legislative procedures - doors to the City Council were closed and access limited. The State Prosecutor's Office filed a challenge to the vote of the proposition, but the request was ignored by the Chairman of the Council (ALCÂNTARA; BORGES, 2015, p. 93-94).

Consequently, again, there was a new occupation. This time, protesters took to the home of the mayor, who signed off on the project. The occupation lasted 3 days and gathered over 200 people. The State Justice Court then ordered the eviction of the occupiers. This was

\footnotetext{
9 Bill of Review Appeal 0005599-81.2014.8.17.0000 (Court of Justice, Pernambuco), by Novo Recife Empreendimentos Ltda (BRASIL, 2018).
} 
the second most significant on-site act organized by the movement (FLORES; GOMES, 2017, p. 232).

However, in December 2015, the New Recife Project was approved in the Council of Urban Development with 21 favorable votes, 2 opposing, 2 abstentions (IPHAN and the Council of Architecture and Urban Planning). After the approval of the urban development plan, the Consortium would have to present a building license.

In the end, the New Recife Project, as it was approved had its impact reduced to 10 residential buildings (1042 apartments), one company, one mixed building (for both apartments and businesses), and a 308-room hotel. The old warehouses will have to be re-fitted to house a Cultural center. $65 \%$ of the area will remain public, and there is a provision that new public transportation access points as well as bicycle lanes will be put in place. A close-by overpass that compromises the architectural integrity of the region will be demolished, land in the Central Avenue will be expropriated, surrounding streets will be expanded, and a 700 square meter library will be built along with public six sports courts. The approved project established 16 mitigating actions, including the construction of a linear public park in nearby neighborhoods - Pina and Bairro do Recife.

At the time we write this article (March 2018), with the deep economic and political crisis Brazil has gone through, work at the site has not yet begun.

\section{CONCLUSIONS}

Studying judicialization as a strategy for social and political groups (legal mobilization), as we have seen throughout this article, demands the examination of the specific interests and contexts where it takes place in order to analyze its normative conditions, trajectories and choices in light of their consequences.

In the case we examined, we saw the constitution of a movement that had the goal of debating urban development in the city with a broad support for mechanisms of popular participation in public disputes. We should note how innovative they were in their mobilization: occupying public (or even private) spaces, using electronic media and online tools, creating a network of adherents. They managed to build a narrative to engage people who were interested in the subject, "utilizing the cultural and affective memory of the Recife dweller to strengthen their discourse" (FLORES; GOMES, 2017, p. 246). We took into account that claiming the right to the city "comes from allowing ourselves, as citizens, to have and use public spaces 
of the city to reinforce principles such as conviviality, harmony, occupation, and manifestation" (BARBOSA, 2017, p. 4).

It is evident how the mobilization profited from these strategies. Economic and political interests were mapped, the role of state and social actors was understood, and people were made aware of their potential to mobilize.

At the same time, they employed traditional channels of representation, such as the majoritarian government branches. Law was used there in order to appeal to the rules that underlie state actions for environmental protection and other instruments of administrative law.

The executive branch was called upon at every turn to answer questions on several matters: on compliance with environmental regulations, the possibility of turning the area into a cultural heritage managed site, the illegality of the land auction, and democratic participation instruments, such as public hearings and representative councils. In the legislative arena, the movement exerted pressure over elected officials and sought to find adherents to their causes.

Appealing to the judicial branch was one their strategies, articulated within state bodies, as effective legal mobilization uses "diversified legal forums [to increase] political participation" (ZEMANS, 1983, p. 700). The many involved parties provided the case with the peculiar tones of a "judicial battle." Litigation was filed by state and federal prosecutors. The complexity of responsibility over the environment allowed many rights to be invoked and various public entities to get involved.

Rulings, in the end, were unfavorable, since development was resumed, though it was required to comply with many regulations. Over the entire period, however, we can see that the movement achieved numerous victories: for instance, time was a stumbling block, since the Consortium was unable to start work as expected, with greater financial and political costs to those involved. The obstruction of public policy required a broader debate in the government on the impacts of land development. Impact was reduced, the project was retooled to conform to sustainability and natural, artificial, cultural, and work environment regulations.

We may confidently state, therefore, that the actions performed by the movement that coalesced around the José Estelita Wharf were able to achieve one of the goals of the Environmental Constitutional State: the awareness that public participation is a corollary to the right to the city. 


\section{REFERENCES}

ALCÂNTARA, Christianne; BORGES, Sheila. O \#ocupeestelita e a nova agenda política do Recife. Revista Passagens - Programa de Pós-Graduação em Comunicação da Universidade Federal do Ceará, v. 6, n. 2, p. 91-107, 2015.

BARBOSA, David Tavares. Ocupe Estelita: Fé, palavras e ações na política urbana da cidade do Recife. Anais do XVII ENANPUR, São Paulo. Disponível em: http://anpur.org.br/xviienanpur/principal/publicacoes/XVII.ENANPUR_Anais/ST_Sessoes_Temat icas/ST\%209/ST\%209.2/ST\%209.2-03.pdf. Acesso em: 16 fev. 2018.

BENJAMIN, Antônio Herman. Constitucionalização do ambiente e ecologização da Constituição brasileira. In: CANOTILHO, José Joaquim Gomes; MORATO LEITE, José Rubens (orgs.). Direito constitucional ambiental brasileiro. São Paulo: Saraiva, 2007, p. 77-150.

BRASIL. Constituição da República Federativa do Brasil, de 5 de outubro de 1988. Diário Oficial da União. Rio de Janeiro, 1988. Disponível em: http://www.planalto.gov.br/ccivil_03/constituicao/constituicaocompilado.htm. Acesso em: 17 mar. 2018.

BRASIL. Instituto Brasileiro de Geografia e Estatística. Recife PE - IBGE Cidades. Disponível em: https://cidades.ibge.gov.br/brasil/pe/recife. Acesso em: 16 fev. 2018.

BRASIL. Justiça Federal em Pernambuco. 12a Vara Federal. Ação Civil Pública 000129134.2013.4.05.8300. Diário de Justiça da União. Disponível em: http://tebas.jfpe.jus.br/consultaProcessos/resconsproc.asp. Acesso em: 12 out. 2016.

BRASIL. Lei no 6.938, de 31 de agosto de 1981. Dispõe sobre a Política Nacional do Meio Ambiente, seus fins e mecanismos de formulação e aplicação, e dá outras providências. Diário Oficial da União. Brasília, DF, 02 set. 1981. Disponível em: http://www.planalto.gov.br/ccivil_03/leis/l6938.htm. Acesso em: 17 mar. 2018. 
BRASIL. Lei 10.257 de 10 de julho de 2001. Regulamenta os artigos 182 e 183 da Constituição Federal, estabelece diretrizes gerais da política urbana e dá outras providências. Diário Oficial da União. Brasília, DF, 11 jul. 2001. Disponível em: http://www.planalto.gov.br/Ccivil_03/leis/LEIS_2001/L10257.htm. Acesso em: 17 mar. 2018.

BRASIL. Tribunal de Justiça de Pernambuco. Agravo de Instrumento 0005599-81.2014.8.17.0000 (337143-3). 4ạ Câmara Cível. Relator: Des. Jones Figueirêdo. Diário de Justiça do Estado. Recife, PE, 04 jun. 2014.

CANOTILHO, José Joaquim Gomes. Estado de Direito. Cadernos Democráticos, n. 7. Lisboa: Gradiva, 1998.

CANOTILHO, José Joaquim Gomes. Estado constitucional ecológico e democracia sustentada. In: SARLET, Ingo Wolfgang (org.). Direitos fundamentais sociais: estudos de direito constitucional, internacional e comparado. Rio de Janeiro/São Paulo: Renovar, 2003, p. 493-508.

CARVALHO, Ernani Rodrigues de. Trajetória da revisão de constitucionalidade no desenho institucional brasileiro: tutela, autonomia e judicialização. Sociologias, Porto Alegre, ano 12, n. 23, p. 176-207, jan./abr. 2010.

CASAgRANDE, Cássio. Ministério Público e judicialização da política - estudos de casos. Porto Alegre: Safe, 2008.

CASTRO, Carlos Roberto Siqueira. A constituição aberta e os direitos fundamentais: ensaios sobre o constitucionalismo pós-moderno e comunitário. Rio de Janeiro: Forense, 2005.

CAVALCANTI, Davi Barboza. Redes sociais virtuais como instrumentos de mobilização política: uma análise do grupo "Direitos Urbanos/Recife" no Facebook. Dissertação (Mestrado em Sociologia) - Universidade Federal de Pernambuco, Recife, 2016.

CITTADINO, Gisele. Pluralismo, direito e justiça distributiva: elementos da filosofia constitucional contemporânea. Rio de Janeiro: Lumen Juris, 2000. 
COSTA, Julie Hanna de Souza Cruz Itinerários de uma intervenção urbana: o movimento \#OcupeEstelita e a luta pelo direito à cidade no Recife. Percursos - Revista de Antropologia, v. 2, n. 1, p. 76-89, 2016.

DICKSON, Brice. Comparing supreme courts. In: DICKSON, Brice (org.). Judicial activism in common law supreme courts. London: Oxford University Press, 2007, p. 1-18.

EPP, Charles R.. The rights revolution - lawyers, activists, and Supreme Court in comparative perspectives. Chicago: The University of Chicago Press, 1998.

FALCÃO, Joaquim; CERDEIRA, Pablo de Camargo; ARGUELHES, Diego Werneck. Relatório Supremo em números - o múltiplo Supremo. Rio de Janeiro: Fundação Getúlio Vargas, 2011.

FIORILLO, Celso Antonio Pacheco. Curso de Direito Ambiental Brasileiro. 4 ed. São Paulo: Saraiva, 2001.

FLORES, Natália Martins; GOMES, Isaltina Maria de Azevedo Melo. \#OcupeEstelita: ciberativismo e mobilização social. C\&S - São Bernardo do Campo, v. 39, n. 1, p. 219-251, 2017.

FRIEDMAN, Barry. The politics of judicial review. Texas Law Review, v. 84, n. 2, p. 257-337, dec. 2005.

GALANTER, Marc. Direito em abundância: a actividade legislativa no Atlântico Norte. Revista Crítica de Ciências Sociais, n. 36, p. 103-145, fev./1993.

GINSBURG, Tom. Judicial review in new democracies: constitutional courts in asian cases. New York: Cambridge University Press, 2003.

GLOPPEN, Siri; GARGARELLA, Roberto; SKAAR, Elin. Democratization and the judiciary: the accountability function of courts in new democracies. London: Frank Cass Publishers, 2004. 
BENJAMIN, Antônio Herman. Constitucionalização do ambiente e ecologização da Constituição brasileira. In: CANOTILHO, José Joaquim Gomes; MORATO LEITE, José Rubens (orgs.). Direito constitucional ambiental brasileiro. São Paulo: Saraiva, 2007, p. 77-150.

HANDLER, Joel F. Social movements and the legal system: a theory of law reform. New York: Academic Press, 1978.

KRELL, Andreas Joachim. Autonomia municipal e proteção ambiental: critérios para definição das competências legislativas e das políticas locais. In: KRELL, Andreas Joachim. (org), A aplicação do Direito Ambiental no Estado federativo. Rio de Janeiro: Lumen Juris. 2005, p. 147203.

LIMA, Flávia Danielle Santiago. Jurisdição constitucional e política: ativismo e autocontenção no STF. Curitiba: Juruá, 2014.

MACHADO, Paulo Affonso Leme. Direito ambiental brasileiro. 15 ed. São Paulo: Malheiros, 2007.

MILARÉ, Édis. Direito do ambiente. 5 ed. São Paulo: Revista dos Tribunais, 2007.

MCCANN, Michael W.. Rights at work: pay equity reform and the politics of legal mobilization. Chicago, IL: University of Chicago Press, 1994.

MCCANN, Michael. Law and Social Movements. In: SARAT, Austin (org). The blackwell companion to law and society. Oxford: Blackwell, 2004, p. 506-522.

MELLO, Cláudio Ari. Elementos para uma teoria jurídica do direito à cidade. Revista de Direito da Cidade, v. 9, n. 2, p. 437-462, 2017.

NEJAIME, Douglas. The legal mobilization dilema. Emory Law Journal, v. 61, p. 663-736, 2012.

NEJAIME, Douglas. Winning through losing. lowa Law Review, v. 96, p. 941-1012, 2011. 
POST, Robert; SIEGEL, Reva. Roe rage: democratic constitutionalism and backlash. Yale Law School, Public Law Working Paper n. 131, p. 1-67, 2007.

ROSENBERG, Gerald. N. The hollow hope: can courts bring about social change? Chigago: University of Chicago Press, 2008.

SARLET, Ingo; FENSTERSEIFER, Tiago. Estado socioambiental e mínimo existencial (ecológico?): algumas aproximações. In: SARLET, Ingo Wolfgang. Estado socioambiental e direitos fundamentais. Porto Alegre: Livraria do Advogado, 2010. p. 11-38.

SILVA, José Afonso da. Direito ambiental constitucional. São Paulo: Malheiros, 1994.

SILVA, Vasco Manuel Dias Pereira Silva. Verde cor de direito: lições de direito do ambiente. Coimbra: Almedina, 2002.

SHAPIRO, Martin; SWEET, Alec Stone. On law, politics, judicialization. New York: Oxford University Press, 2002.

SWEET, Alec Stone. Governing with judges - constitutional politics in Europe. Oxford: Oxford University Press, 2000.

TATE, C. Neal. Why the expansion of judicial power?. TATE, C. Neal; VALLINDER, Torbjörn (orgs.). The global expansion of judicial power. New York: New York University Press, 1995, p. 28-36.

TAYLOR, Matthew M.. O Judiciário e as políticas públicas no Brasil. DADOS - Revista de Ciências Sociais, Rio de Janeiro, v. 50, n. 2, p. 229-257, 2007.

TAYLOR, Matthew M.; DA ROS, Luciano. Os partidos dentro e fora do poder: a judicialização como resultado contingente da estratégia política. DADOS - Revista de Ciências Sociais, Rio de Janeiro, v. 51, n. 4, p. 825-864, 2008.

TORRES, Ricardo José; CHRISTOFOLETTI, Rogério. O caso Ocupe Estelita e a emergência de novas vozes no debate político. Esferas, v. 7, p. 173-182, 2015. 
TRINDADE, Thiago Aparecido. Direitos e cidadania: reflexões sobre o direito à cidade. Lua Nova, n. 87, p. 139-165, 2012.

TUSHNET, Mark. Weak courts, strong rights: judicial review and social welfare rights in comparative constitutional law. Princeton: Princeton University Press, 2008.

VIANNA, Luiz Werneck et al. A judicialização da política e das relações sociais no Brasil. Rio de Janeiro: Revan, 1999.

VIANNA, Luiz Werneck; BURGOS, Marcelo Baumann; SALLES, Paula Martins. Dezessete anos de judicialização da política. Tempo Social (Revista de Sociologia da USP), v.19, n. 2, p. 39-85, 2007.

VIANNA, Luiz Werneck; BURGOS, Marcelo. Revolução processual do Direito e democracia progressiva. In: VIANNA, Luiz Werneck (org.). A democracia e os três poderes no Brasil. Belo Horizonte: UFMG; Rio de Janeiro: IUPERJ/FAPERJ, 2002, p. 337-491.

WHITTINGTON, Keith E.; KELEMEN, R. Daniel; CALDEIRA, Gregory A. (eds.) The Oxford handbook of law and politics. Oxford: Oxford University Press, 2008.

ZEMANS, Frances Kahn. Legal mobilization: the neglected role of the law in the political system. The American Political Science Review, v. 77, n. 3. p. 690-703, set., 1983.

Trabalho enviado em 20 de março de 2018

Aceito em 22 de maio de 2018 